\title{
PRIVATE GUARANTEES FOR MUNICIPAL BONDS: EVIDENCE FROM THE AFTERMARKET**
}

\author{
JOHN M. QUIGLEY* AND DANIEL L. RUBINFELD*
}

\section{ABSTRACT}

This paper considers the market for private guarantees for municipal debt. It reviews the empirical evidence on the effects of insurance upon the pricing of new is sues. It also presents the first empirical evidence available on the effects of bond insurance in the aftermarket for tax exempt securities. Aftermarket trades in identical securities in insured and uninsured forms are used to estimate the effect of insurance upon the true yield of the bonds and the sale price of those bonds. The effect of bond insurance upon yields and during 1987-89 is estimated to be substantial-14 to 28 basis points in terms of yield, or 1.9 to 3.9 percent in terms of the quoted prices for municipal securities with 30-year maturities.

D URING the past decade there has been an astonishing increase in the incidence of guarantees for the securities issued by state and local governments. A wide and diverse variety of public programs provide some form of credit enhancement for local issues. These programs include state bond banks, revolving loan funds ("credit pools"), debt service guarantees, and a range of explicit assurances. Direct state guarantees include programs providing full collateralization (Texas), full-faith-and-credit backing by the state, state-administered insurance programs (Minnesota), more complex pledges of future tax revenues, and sometimes pledges to divert unrelated state funds to bondholders under certain conditions. $^{1}$

But the most important addition to the complex patchwork of guarantees has come from the private sector. The provision of guarantees by private profit-making firms for the debt issued by public agencies has been transformed from a niche in the fi-

\footnotetext{
*University of California, Berkeley, CA 94720.
}

nancial services industry to a major component of that industry.

This paper presents new evidence on the pricing of private guarantees. In Section 1 we describe briefly the operation of the industry and the recent history of its expansion. ${ }^{2}$ Section 2 considers the microeconomics of bond guarantees and surveys existing econometric evidence on the pricing of insurance in the market for newly-issued debt. This section also presents the first empirical evidence available on the pricing of bond insurance in the resale market (or "aftermarket") for municipal bonds. This empirical analysis is based upon a unique body of micro data on bond trades during the period 19871989. The data consist of observations on the trades of bonds which are "identical twins"; in each case the underlying security was originally issued without insurance, but some part of the issue was subsequently insured in the aftermarket.

Conclusions are presented, briefly, in Section 3.

\section{Private Municipal Bond Guarantees}

A variety of private firms and government agencies provide some form of guarantee or insurance for the timely payment of municipal bond obligations. This enhancement of the creditworthiness of municipal bonds affects the cost of borrowing by local governments and the extent of the market for the securities issued by those governments.

The net cost of borrowing is affected by the cost of insurance, but also by the fact that the more secure guaranteed bonds with higher credit ratings can be marketed to investors at lower interest costs to the issuer. The routine award of AAA credit ratings for these securities, based on the credit history of the guarantor, increases the liquidity of the bonds, particularly those issued by smaller jurisdic- 
tions without independent ratings.

There are two principal forms of private credit enhancement: bond insurance and standby letters of credit. In addition, there exists at least one other variantthe so-called guaranteed investment contract.

Private insurance for municipal bonds may be purchased by local governments at the time the bonds are offered to investors. The insurance is irrevocable and extends for the life of the issue. Premiums are negotiated individually between insurance firms and public agencies. Depending upon the creditworthiness of the issuer, bond premiums are in the range of 0.1 to 2.0 percent of the undiscounted sum of principal and interest for the issue. The average premium is reported to be 0.8 percent of the simple sum of principal and interest (Bland and Yu [1987]). The insurer agrees to guarantee the timely payment of principal and interest to investors in return for the one-time premium paid on the issue date of the securities. About two-thirds of the premiums for municipal bond insurance are generated in this way at the initial issue of the security (Rindlaub [1986]). The other third of bond premiums is generated in the "aftermarket," that is, after the security has been issued and purchased by the initial investors.

The second principal form of private credit enhancement is the standby letter of credit, a commitment by a commercial bank to pay principal and interest in the event the issuer cannot. Unlike private insurance extended for the life of a security, letters of credit are extended for short periods, usually terms of five years or less.

Although standby letters of credit have been utilized for decades, municipal bond insurance apparently began only in 1971 with the formation of the Municipal Bond Insurance Corporation. The market for insurance was small until the celebrated failure of the Washington Public Power Supply System (WPPSS) in $1983 .^{3}$

Figure 1 indicates the course of private credit enhancements during the past decade. In 1981 less than 10 percent of new issues carried private credit enhancement, and only three percent were in- sured. However, by 1985 the incidence of credit enhancement increased to about 37 percent of new issues. In 1985 about onefifth of the dollar volume of new issues was backed by municipal bond insurance. During this period, the number and volume of new issues increased, driven by the need to finance new public infrastructure (or by a rush on the part of issuers to get to market before passage of the Tax Reform Act, many of whose provisions went into effect in August, 1986).

In absolute terms, the growth in private credit enhancement was even more impressive. Between 1981 and 1985, the dollar volume of privately-insured issues increased by almost 1900 percent, from $\$ 2.4$ to $\$ 44.5$ million, while the volume of municipals backed by letters of credit increased by about 800 percent.

In addition to these two forms of insurance, guarantees of investment returns have been provided in certain instances to enhance the credit of municipal bonds. Under guaranteed investment contracts, some fraction of the proceeds of a bond sale is deposited with the insurer, who guarantees a specified return on this investment for a specific period and the timely return of principal at the expiration of the period. ${ }^{4}$

Finally, as noted above, municipal bonds may be privately insured when they are traded in the "aftermarket." In this case, insurance is purchased for only some portion of a particular bond issue. For example, the individual bonds comprising a unit trust portfolio may be insured for their remaining lives. Alternatively, a fund or portfolio as a whole may be insured. In this case, the insurer may guarantee timely payment of principal and interest on the component bonds only as long as they remain in the portfolio. ${ }^{5}$ Third party insurance for some part of a bond issue may also be arranged by broker dealers who then offer the credit-enhanced securities for sale through their trading or retail desks.

The value of any of these guarantees depends entirely upon the creditworthiness of the insurer, as perceived in financial markets. Thus the market for standby letters of credit is dominated by large in- 
FIGURE 1

A. Incidence of Private Insurance

1980-1989

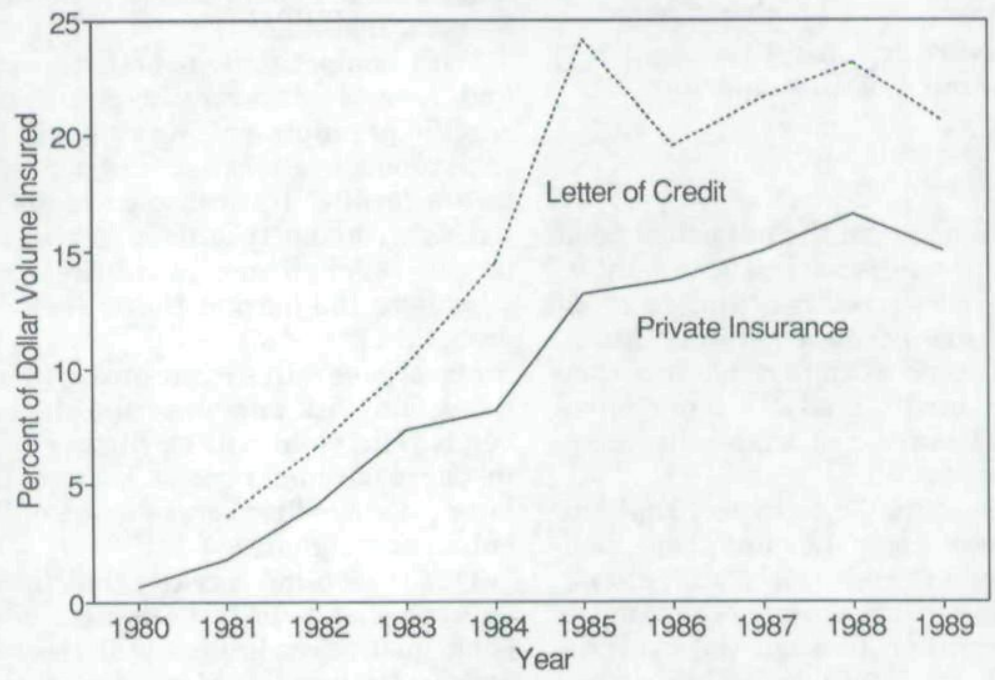

B. Volume of Private Insurance 1980-1989

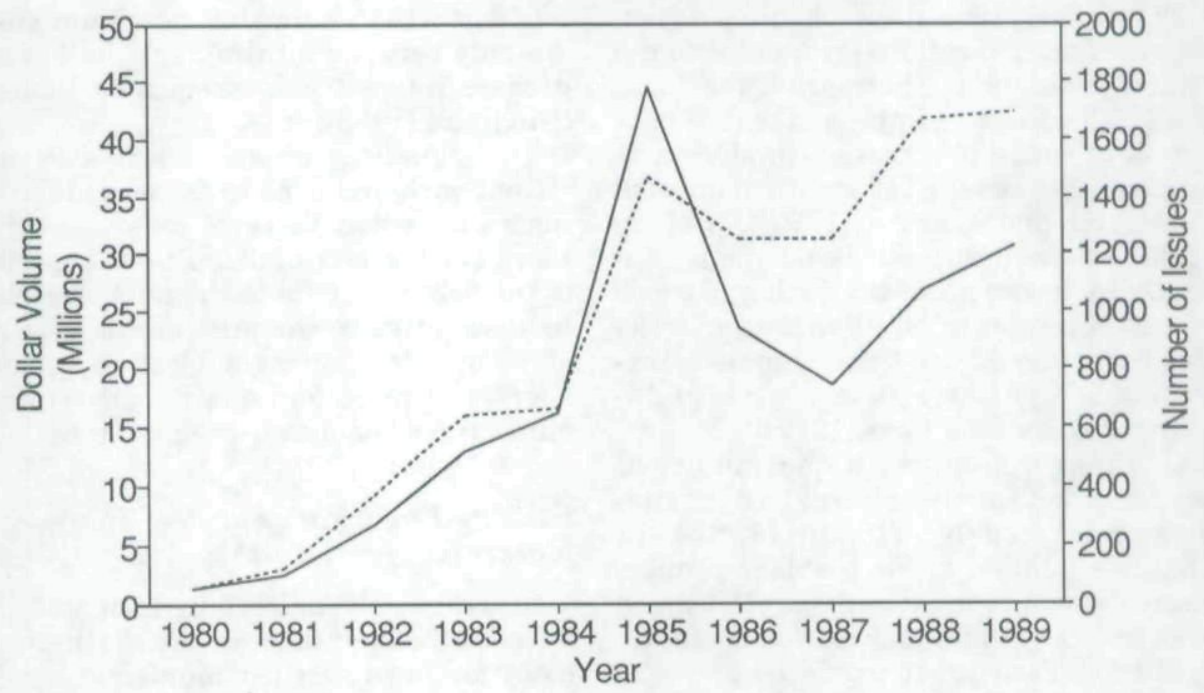

- Private Insurance ….... Number of Issues 
ternational banks with AAA credit ratings. The loss of a AAA rating by a bond insurance firm is a major calamity.

\section{Bond Insurance and the Microeconomics of Information}

\section{Conceptual Issues}

Clearly, all actors in the municipal bond market do not possess the same information about the creditworthiness of issuers. Presumably those offering financial guarantees do so, in part, because they can provide credit analysis more effectively and at lower cost than other market participants can.

It seems reasonable to expect that the issuers of bonds know the most about their own capacities to repay debt obligations. Those offering insurance can obtain much of this information through the expenditure of funds for "research," while potential holders of the obligations would have to invest even more to obtain equivalent information. Insurance offerings provide information in this world of asymmetric information.

This characterization of information suggests several rational responses to the failure inherent in the market for "lemons." Sellers could simply make side payments to cause information producers to acquire and reveal information on risk (Campbell and Kracow [1980]). ${ }^{6}$ Sellers could be encouraged to issue costly signals of their own about the quality of bonds offered for sale; in equilibrium, prospective buyers could use these signals to discriminate accurately among bonds of differing quality (See Ross [1977]).

Of direct relevance to the municipal bond market is the alternative mechanism analyzed by Thakor [1982]. In Thakor's solution to the problem of information asymmetry, third parties spend resources to produce information about the quality of each product offered for sale; they use this information to structure and to price a fixed quality service that they provide to the sellers of the variable-quality product. The seller of each product chooses a desired service level; this choice is itself a signal to the market about the quality of the product. In Thakor's model the "third parties" may be bond insurers, and the "fixed quality service" offered may be bond insurance.

With competition in both the product and service markets, in equilibrium a specific premium pricing rule will induce each product seller (issuer of bonds) to obtain a level of insurance coverage which varies with the true default risk known to the seller. Thus, insurance coverage signals to the market the seller's default probability.

More generally, insurance will reduce the default risk and lower the yield on the bonds. The yield will be further reduced, in these circumstances, because insurance coverage also serves as an efficiency enhancing signal.

This reasoning suggests that there will be net benefits to those issuers choosing bond insurance. Issuers will receive cost savings (in terms of lower required yields) in excess of the costs of purchasing insurance, reflecting the value of the signal emitted by the purchase of bond insurance.

This signalling implication is consistent with the claim that premium costs are only between a third and a half of aggregate interest cost savings to issuers. (Rindlaub [1986]).

The signalling implication is also consistent with decisions by issuers to forego insurance when there is consensus that there is little risk of default-the pricing of the debt under these circumstances will be insensitive to the presence or absence of insurance. Issuers subject to greater degrees of price and quality uncertainty gain larger benefits from insurance.

\section{Existing Empirical Evidence: The Market for New Issues}

Several analysts have investigated the effect of bond insurance on the interest costs for newly issued municipal bonds. These studies are typically based upon a sample of issues whose sales are reported in the Daily Bond Buyer, the newspaper of record for the municipal bond industry. ${ }^{7}$ 
For these sales, the reported net interest cost (NIC) to the borrower is compared for insured and uninsured placements. NIC is easily obtainable from Bond Buyer reports, but it is not really comparable to a present value or a yield. ${ }^{8}$

Bland and Yu [1987], for example, compared the NIC of 445 insured and 694 uninsured bonds offered in 1985. Regression relationships using dummy variables reflecting Moody's credit ratings as independent variables revealed a clear inverse relationship between credit rating and NIC, with privately insured bonds trading at NIC's between A and Baa-1. Ceteris paribus, insured bonds sold at about 20 basis points higher in terms of NIC than Aaa-rated municipals. Bland and $\mathrm{Yu}$ used similar regression techniques to estimate the NIC savings from insurance at various levels of underlying creditworthiness, concluding that insurance is only "cost effective" for issues with underlying ratings of Baa-1 or that are unrated. It is "likely that the savings in NIC compensate for the premium cost of insurance only in these cases." (Bland and Yu [1987]).

Other work by Bland [1987], including analyses of several hundred bond offerings in New Jersey, 1981-1984, and in Texas, 1983-1984, yields similar conclusions. Net interest costs at issue are significantly higher for privately-insured bonds than for bonds whose underlying risk is judged by Moody's to be Aaa. Issues with private insurance trade somewhere between the prices of $\mathrm{A}$ and Baa-1 securities.

Recent work by Kidwell, et al [1987] carries the analysis one step farther by utilizing sensitive internal firm information about the prices charged for municipal bond insurance. Kidwell et al gathered NIC and other information from the Daily Bond Buyer for a sample of some 2700 general obligation bonds sold in 1975-1980. For the uninsured bonds in this sample, they estimated a regression relationship between NIC and the characteristics of the issue and market, as well as the geographical region of the issuer.

Forecasts from this regression, together with information on insurance costs, permitted the net benefits to be estimated for those issuers who chose bond insurance. On average, gross benefits were estimated to be 34.1 basis points in reduced yield, at an average insurance premium of 11.7 basis points-leaving average net benefits of 22.4 basis points. On average, net benefits of insurance varied inversely with Moody's quality rating and were insignificantly different from zero for the highest-rated bonds ( $\mathrm{Aa}$ in this sample).

In general, the results of the Kidwell analysis suggest that the innovation of bond insurance has increased market efficiency. The alternative explanation, that somehow the oligopolistic insurers leave set prices too low, seems less credible.

\section{New Evidence: The Aftermarket}

As noted previously, about a third of the premium income in the municipal bond industry is generated in the aftermarket. The analysis of aftermarket transactions provides a unique opportunity to observe the effects of insurance on bond yields. This is because only a fraction of any given security, which originally had been issued without insurance, is offered for sale with insurance in the aftermarket. Thus it is possible to observe precisely the same security, and its underlying credit risk, trading with and without third party insurance.

For many years Kenny Information Systems, Inc. ("Kennybase") has acted as a principal information clearing house for the aftermarket in municipal bonds. The firm provided us with a random sample of trades during the period 1987-1989 of securities insured in the aftermarket. From its data base, Kennybase also provided us with all the other trades during the same period on those same securities-trades which were not insured by any third party. This analysis concentrates on bonds issued without call provisions in any form and insured by a single monoline insurance firm.

The available data for each trade include the maturity of the issue, the semiannual coupon, the date of the trade, the Moody's and/or S\&P rating of the issue on the date of trade, as well as the "basis" (interest rate) and any "concession" (dol- 
lar premium or discount) for that trade.

From the basis, concession, and maturity, the dollar price associated with each trade can be computed. Because we consider only bonds without call provisions, the maturity, the coupon, and the dollar price so computed uniquely determine the true yield or interest rate at which each trade occurred.

Altogether, the data include observations on 1772 trades on 110 different issues during the three-year period-317 observations on trades in insured securities and 1455 observations on trades in the uninsured versions of those same securities.

To these data on securities, we have appended the Moody's Aaa Index and the Baa Index for the week of the trade, as well as the Composite Index of long-term Treasury securities. ${ }^{9}$

Table 1 presents the average characteristics of the securities traded in insured and uninsured forms during the three-year period. The average coupon rate of insured and uninsured bonds was virtually identical. The basis and concessions for uninsured bonds were somewhat higher, translating into sales prices (presented relative to par) higher by $\$ 5.50$. When all attributes of the sale are considered, the yield averaged 7.836 percent for uninsured bonds and 7.392 for insured bonds.

The composite indices vary somewhat for the two samples, reflecting only the timing of transactions. Among uninsured bonds, the modal Moody's rating was A1, bonds with the "strongest investment attributes" among the class of "upper medium grade obligations." According to Standard and Poor's classification, the modal rating among trades in uninsured bonds was AA, indicating debt with "a very strong capacity to pay interest and repay principal"; a large portion was rated A, indicating a "strong capacity to repay."

With bond insurance, the same underlying risks of the issuer were rated much higher by the agencies, and 90 percent of the trades were considered to be Aaa and AAA, the highest ratings for municipal debt awarded by Moody's and Standard and Poor's respectively.
Table 2 presents regressions of the bond yields on the three indices representing time-varying interest rates. ${ }^{10}$ Clearly a great deal of the variation in bond yields during this period is attributable to temporal changes in interest rates. We have no strong prior on the appropriate representation of rates; it appears that the yields in this sample more closely follow the index of yields on investment grade (Baa) tax-exempt securities, but the differences in overall fit for the regressions reported in columns 1,2 , and 3 are quite small. Each regression includes eight dummy variables indicating the Moody's rating for uninsured bonds and a dummy variable signifying insured bonds. With one inexplicable exception, the coefficients indicate that higher yields are required for bonds with lower credit ratings. ${ }^{11}$

Columns 4, 5, and 6 add three variables indicating the size of the trade: less than 10 bonds, 10 to 99 bonds, 100 to 999 bonds. Relative to the omitted category, small volume trades are priced substantially higher.

The results in Table 2 indicate that bond insurance has an important effect upon the yields for bonds traded in the aftermarket. According to the estimated coefficients, insurance lowers the yield on bonds by 8 to 27 basis points (relative to an average yield to maturity of 7.77 percent).

The "twins" feature of the data permits the effect of insurance on bond pricing to be measured more precisely. The data set includes at least two observations on each security and at least one observation on the insured version of each security. We can thus hold constant the underlying creditworthiness of each issue by a set of dummy variables representing the different securities. ${ }^{12}$

Table 3 presents the results of regressions on bond yields when 109 dummy variables representing each underlying security are included in the model, instead of the cruder credit rating categories. The explained variance of the model increases substantially; roughly four-fifths of the variance in bond yields is explained by the model. The importance of interest 
TABLE 1

AVERAGE CHARACTERISTICS OF SAMPLE OF AFTERMARKET TRANSACTIONS (STANDARD DEVIATIONS IN PARENTHESES)

\begin{tabular}{|c|c|c|c|}
\hline & $\begin{array}{l}\text { All } \\
\text { Sales } \\
\end{array}$ & $\begin{array}{l}\text { Uninsured } \\
\text { Only }\end{array}$ & $\begin{array}{l}\text { Insured } \\
\text { Only } \\
\end{array}$ \\
\hline $\begin{array}{l}\text { Coupon } \\
\text { (percent) }\end{array}$ & $\begin{array}{r}6.201 \\
(2.10)\end{array}$ & $\begin{array}{r}6.203 \\
(2.06)\end{array}$ & $\begin{array}{l}6.193 \\
(2.25)\end{array}$ \\
\hline $\begin{array}{l}\text { Dollar Price } \\
(\operatorname{Par}=\$ 100)\end{array}$ & $\begin{array}{r}84.522 \\
(21.06)\end{array}$ & $\begin{array}{c}83.542 \\
(21.25)\end{array}$ & $\begin{array}{r}89.022 \\
(19.57)\end{array}$ \\
\hline $\begin{array}{l}\text { Basis } \\
\text { (percent) }\end{array}$ & $\begin{array}{r}4.651 \\
(3.75)\end{array}$ & $\begin{array}{r}4.706 \\
(3.79)\end{array}$ & $\begin{array}{r}4.397 \\
(3.56)\end{array}$ \\
\hline $\begin{array}{l}\text { Concession } \\
\text { (dollars) }\end{array}$ & $\begin{array}{l}-5.463 \\
(7.10)\end{array}$ & $\begin{array}{l}-5.607 \\
(7.24)\end{array}$ & $\begin{array}{l}-4.802 \\
(6.33)\end{array}$ \\
\hline $\begin{array}{l}\text { Size of trade } \\
\text { (thousands) }\end{array}$ & $\begin{array}{c}427.65 \\
(1113.36)\end{array}$ & $\begin{array}{r}420.137 \\
(1149.47)\end{array}$ & $\begin{array}{r}462.129 \\
(930.58)\end{array}$ \\
\hline $\begin{array}{l}\text { Yield } \\
\text { (percent) }\end{array}$ & $\begin{array}{r}7.766 \\
(0.73)\end{array}$ & $\begin{array}{r}7.836 \\
(0.73)\end{array}$ & $\begin{array}{l}7.392 \\
(0.62)\end{array}$ \\
\hline $\begin{array}{l}\text { Aaa index } \\
\text { (percent) }\end{array}$ & $\begin{array}{r}7.144 \\
(0.45)\end{array}$ & $\begin{array}{l}7.152 \\
(0.46)\end{array}$ & $\begin{array}{r}7.106 \\
(0.40)\end{array}$ \\
\hline $\begin{array}{l}\text { Baa index } \\
\text { (percent) }\end{array}$ & $\begin{array}{r}7.810 \\
(0.58)\end{array}$ & $\begin{array}{r}7.841 \\
(0.59)\end{array}$ & $\begin{array}{l}7.661 \\
(0.52)\end{array}$ \\
\hline $\begin{array}{l}\text { Fed index } \\
\text { (percent) }\end{array}$ & $\begin{array}{r}8.697 \\
(0.55)\end{array}$ & $\begin{array}{r}8.703 \\
(0.56)\end{array}$ & $\begin{array}{r}8.670 \\
(0.51)\end{array}$ \\
\hline $\begin{array}{l}\text { Moody's (percen } \\
\text { Unrated } \\
\text { Baa } \\
\text { Baa1 } \\
\text { A2 } \\
\text { A } \\
\text { A1 } \\
\mathrm{Aa} 3 \\
\mathrm{Aa} 2 \\
\mathrm{Aa} \\
\mathrm{Aaa}\end{array}$ & $\begin{array}{l}0.016 \\
0.015 \\
0.003 \\
0.005 \\
0.224 \\
0.394 \\
0.001 \\
0.011 \\
0.157 \\
0.171\end{array}$ & $\begin{array}{l}0.014 \\
0.018 \\
0.004 \\
0.006 \\
0.269 \\
0.469 \\
0.001 \\
0.014 \\
0.190 \\
0.013\end{array}$ & $\begin{array}{l}0.025 \\
0.000 \\
0.000 \\
0.000 \\
0.016 \\
0.050 \\
0.000 \\
0.000 \\
0.003 \\
0.896\end{array}$ \\
\hline $\begin{array}{l}\text { S\&P's (percent) } \\
\text { Unrated } \\
\text { Under review } \\
\text { A }^{-} \\
\mathrm{A}^{+} \\
\mathrm{A}^{+} \\
\mathrm{AA}^{\cdot} \\
\mathrm{AA}^{+} \\
\mathrm{AA}^{+} \\
\mathrm{AAA}^{+}\end{array}$ & $\begin{array}{l}0.022 \\
0.002 \\
0.071 \\
0.253 \\
0.119 \\
0.034 \\
0.320 \\
0.006 \\
0.171\end{array}$ & $\begin{array}{l}0.022 \\
0.001 \\
0.085 \\
0.300 \\
0.144 \\
0.042 \\
0.390 \\
0.006 \\
0.013\end{array}$ & $\begin{array}{l}0.022 \\
0.003 \\
0.006 \\
0.054 \\
0.006 \\
0.000 \\
0.000 \\
0.003 \\
0.896\end{array}$ \\
\hline $\begin{array}{l}\text { Number of } \\
\text { transactions }\end{array}$ & 1772 & 1455 & 317 \\
\hline
\end{tabular}


TABLE 2

REGRESSION ESTIMATES OF MUNICIPAL BOND YIELDS

1771 OBSERVATIONS

(t-ratios in parenthesis)

\begin{tabular}{|c|c|c|c|c|c|c|}
\hline Coefficient & 1 & 2 & 3 & 4 & 5 & 6 \\
\hline \multicolumn{7}{|l|}{ Interest Rate } \\
\hline Aaa Index & $\begin{array}{r}1.011 \\
(37.11)\end{array}$ & & & $\begin{array}{r}1.000 \\
(37.10)\end{array}$ & & \\
\hline Baa Index & & $\begin{array}{r}0.804 \\
(38.26)\end{array}$ & & & $\begin{array}{r}0.799 \\
(38.66)\end{array}$ & \\
\hline Fed Index & & & $\begin{array}{r}0.751 \\
(31.71)\end{array}$ & & & $\begin{array}{r}0.741 \\
(31.48)\end{array}$ \\
\hline \multicolumn{7}{|l|}{$\begin{array}{l}\text { Moody's Rating } \\
\text { Uninsured Issues }\end{array}$} \\
\hline Unrated & $\begin{array}{r}0.292 \\
(2.47)\end{array}$ & $\begin{array}{r}0.154 \\
(1.32)\end{array}$ & $\begin{array}{r}0.220 \\
(1.75)\end{array}$ & $\begin{array}{r}0.360 \\
(3.08)\end{array}$ & $\begin{array}{r}0.236 \\
(2.06)\end{array}$ & $\begin{array}{c}0.283 \\
(2.27)\end{array}$ \\
\hline Baa & $\begin{array}{l}-0.487 \\
(4.56)\end{array}$ & $\begin{array}{l}-0.537 \\
(5.10)\end{array}$ & $\begin{array}{l}-0.479 \\
(4.21)\end{array}$ & $\begin{array}{l}-0.439 \\
(4.16)\end{array}$ & $\begin{array}{l}-0.483 \\
(4.66)\end{array}$ & $\begin{array}{l}-0.437 \\
(3.88)\end{array}$ \\
\hline Baa1 & $\begin{array}{c}0.576 \\
(2.67)\end{array}$ & $\begin{array}{r}0.656 \\
(3.09)\end{array}$ & $\begin{array}{c}0.598 \\
(2.61)\end{array}$ & $\begin{array}{r}0.523 \\
(2.46)\end{array}$ & $\begin{array}{r}0.593 \\
(2.85)\end{array}$ & $\begin{array}{r}0.551 \\
(2.43)\end{array}$ \\
\hline A2 & $\begin{array}{c}0.148 \\
(0.84)\end{array}$ & $\begin{array}{r}0.257 \\
(1.47)\end{array}$ & $\begin{array}{r}0.100 \\
(0.53)\end{array}$ & $\begin{array}{c}0.163 \\
(0.94)\end{array}$ & $\begin{array}{r}0.258 \\
(1.49)\end{array}$ & $\begin{array}{r}0.132 \\
(0.71)\end{array}$ \\
\hline A & $\begin{array}{r}0.048 \\
(1.19)\end{array}$ & $\begin{array}{r}0.079 \\
(2.00)\end{array}$ & $\begin{array}{r}0.034 \\
(0.78)\end{array}$ & $\begin{array}{c}0.099 \\
(2.45)\end{array}$ & $\begin{array}{r}0.135 \\
(8.42)\end{array}$ & $\begin{array}{r}0.086 \\
(1.99)\end{array}$ \\
\hline A1 & $\begin{array}{r}0.264 \\
(7.26)\end{array}$ & $\begin{array}{r}0.273 \\
(7.61)\end{array}$ & $\begin{array}{r}0.245 \\
(6.30)\end{array}$ & $\begin{array}{r}0.289 \\
(8.00)\end{array}$ & $\begin{array}{r}0.299 \\
(8.42)\end{array}$ & $\begin{array}{c}0.271 \\
(7.04)\end{array}$ \\
\hline $\mathrm{Aa} 3$ & $\begin{array}{r}1.530 \\
(4.13)\end{array}$ & $\begin{array}{r}1.350 \\
(3.70)\end{array}$ & $\begin{array}{r}1.423 \\
(3.61)\end{array}$ & $\begin{array}{r}1.627 \\
(4.45)\end{array}$ & $\begin{array}{r}1.469 \\
(7.37)\end{array}$ & $\begin{array}{r}1.506 \\
(3.86)\end{array}$ \\
\hline $\mathrm{Aa} 2$ & $\begin{array}{r}0.767 \\
(6.50)\end{array}$ & $\begin{array}{r}0.826 \\
(7.10)\end{array}$ & $\begin{array}{r}0.756 \\
(6.02)\end{array}$ & $\begin{array}{c}0.788 \\
(6.78)\end{array}$ & $\begin{array}{r}0.841 \\
(7.37)\end{array}$ & $\begin{array}{r}0.781 \\
(6.29)\end{array}$ \\
\hline $\begin{array}{l}\text { Insurance } \\
\text { Amount }\end{array}$ & $\begin{array}{l}-0.228 \\
(5.38)\end{array}$ & $\begin{array}{l}-0.128 \\
(3.05)\end{array}$ & $\begin{array}{l}-0.274 \\
(6.08)\end{array}$ & $\begin{array}{l}-0.181 \\
(4.28)\end{array}$ & $\begin{array}{l}-0.076 \\
(1.83)\end{array}$ & $\begin{array}{l}-0.227 \\
(5.03)\end{array}$ \\
\hline Bonds $<10$ & & & & 0.403 & 0.376 & $\begin{array}{r}0.428 \\
(5.68)\end{array}$ \\
\hline $10 \leq$ Bonds $<100$ & & & & $\begin{array}{c}0.173 \\
(4.38)\end{array}$ & $\begin{array}{r}(3.42) \\
0.190 \\
(4.90)\end{array}$ & $\begin{array}{r}(5.68) \\
0.193 \\
(4.58)\end{array}$ \\
\hline $100 \leq$ Bonds $<1000$ & & & & $\begin{array}{c}0.042 \\
(1.09)\end{array}$ & $\begin{array}{r}0.012 \\
(0.33)\end{array}$ & $\begin{array}{r}0.089 \\
(2.16)\end{array}$ \\
\hline Intercept & $\begin{array}{r}0.457 \\
(2.31)\end{array}$ & $\begin{array}{r}1.378 \\
(8.20)\end{array}$ & $\begin{array}{r}1.168 \\
(5.60)\end{array}$ & $\begin{array}{r}0.402 \\
(2.05)\end{array}$ & $\begin{array}{l}1.286 \\
(7.73)\end{array}$ & $\begin{array}{r}1.102 \\
(5.23)\end{array}$ \\
\hline$R^{2}$ & 0.496 & 0.510 & 0.429 & 0.511 & 0.529 & 0.443 \\
\hline
\end{tabular}

rates in determining bond yields is emphasized in these regression results; the interest rate variables have $t$ ratios in excess of 40. Again, prices are estimated to be significantly higher for small volume trades.

More importantly, the statistical significance of bond insurance in affecting yields is increased and the range of estimated effects of bond insurance is nar- rowed considerably. The results in Table 3 suggest that the value of bond insurance in enhancing the creditworthiness of bonds sold in the aftermarket is between 14 and 28 basis points.

\section{Conclusion}

This paper has analyzed the market for private guarantees for municipal securi- 
TABLE 3

REGRESSION ESTIMATES OF MUNICIPAL BOND YIELDS

1771 OBSERVATIONS

(t-ratios in parenthesis)

\begin{tabular}{|c|c|c|c|c|c|c|}
\hline Coefficient & 1 & 2 & 3. & 4 & 5 & 6 \\
\hline \multicolumn{7}{|l|}{ Interest Rate } \\
\hline Aaa Index & $\begin{array}{r}0.946 \\
(50.22)\end{array}$ & & & $\begin{array}{r}0.947 \\
(50.50)\end{array}$ & & \\
\hline Baa Index & & $\begin{array}{r}0.780 \\
(54.32)\end{array}$ & & & $\begin{array}{r}0.783 \\
(54.93)\end{array}$ & \\
\hline Fed Index & & & $\begin{array}{r}0.707 \\
(41.28)\end{array}$ & & & $\begin{array}{r}0.708 \\
(41.58)\end{array}$ \\
\hline Insurance & $\begin{array}{l}-0.253 \\
(8.23)\end{array}$ & $\begin{array}{c}-0.133 \\
(4.51)\end{array}$ & $\begin{array}{l}-0.277 \\
(8.09)\end{array}$ & $\begin{array}{l}-0.256 \\
(8.38)\end{array}$ & $\begin{array}{l}-0.136 \\
(4.66)\end{array}$ & $\begin{array}{l}-0.283 \\
(8.29)\end{array}$ \\
\hline \multicolumn{7}{|l|}{ Amount } \\
\hline Bonds $<10$ & & & & $\begin{array}{r}0.226 \\
(4.62)\end{array}$ & $\begin{array}{r}0.267 \\
(5.77)\end{array}$ & $\begin{array}{r}0.219 \\
(4.02)\end{array}$ \\
\hline $10 \leq$ Bonds $<100$ & & & & $\begin{array}{r}0.040 \\
(1.33)\end{array}$ & $\begin{array}{r}0.103 \\
(3.66)\end{array}$ & $\begin{array}{r}0.044 \\
(1.33)\end{array}$ \\
\hline $100 \leq$ Bonds $<1000$ & & & & $\begin{array}{c}0.058 \\
(2.13)\end{array}$ & $\begin{array}{r}0.059 \\
(2.28)\end{array}$ & $\begin{array}{r}0.096 \\
(3.15)\end{array}$ \\
\hline Intercept & $\begin{array}{r}1.144 \\
(4.24)\end{array}$ & $\begin{array}{r}1.726 \\
(6.89)\end{array}$ & $\begin{array}{r}1.632 \\
(5.40)\end{array}$ & $\begin{array}{r}1.085 \\
(4.03)\end{array}$ & $\begin{array}{r}1.650 \\
(6.63)\end{array}$ & $\begin{array}{r}1.529 \\
(5.08)\end{array}$ \\
\hline $\mathrm{R}^{2}$ & 0.809 & 0.827 & 0.763 & 0.812 & 0.831 & 0.766 \\
\hline
\end{tabular}

TABLE 4

IMPLIED PERCENTAGE INCREASE IN SALE PRICES ARISING FROM BOND INSURANCE*

Yield Without Insurance

10 Years

Maturity

20 Years

30 Years

A. Assuming insurance saves 14 basis points

$\begin{array}{llll}6.5 \% & 1.032 \% & 1.588 \% & 1.881 \% \\ 7.0 & 1.023 & 1.550 & 1.810 \\ 7.5 & 1.013 & 1.512 & 1.739 \\ 8.0 & 1.010 & 1.476 & 1.672 \\ 8.5 & 0.994 & 1.440 & 1.607\end{array}$

B. Assuming insurance saves 28 basis points

$\begin{array}{llll}6.5 \% & 2.079 \% & 3.212 \% & 3.818 \% \\ 7.0 & 2.059 & 3.134 & 3.672 \\ 7.5 & 2.040 & 3.058 & 3.529 \\ 8.0 & 2.020 & 2.984 & 3.391 \\ 8.5 & 2.001 & 2.910 & 3.259\end{array}$

- Calculations assume semi-annual payments at the sample average coupon rate of 6.201 percent. 
ties and has reviewed existing empirical evidence on the effects of insurance upon the pricing of new issues. The paper also presents new evidence on the perceived effects of bond insurance in reducing the risks associated with holding municipal debt. This new evidence is derived from observations on the true yield of securities traded in the aftermarket in insured and uninsured forms. It suggests that bond insurance lowers the required yield on municipal debt by 14 to 28 basis points.

Table 4 presents an alternative summary of the implications of the statistical analysis. It indicates the effects of the estimated changes in yield upon the sale prices of municipal bonds. These effects vary with the yield, coupon and maturity of securities. For 20-year maturities, at the average coupon rate in the sample, a yield of 6.5 percent implies that bonds sell at 91.468 relative to 100 par. A 14 basis point reduction in true yield, arising from insurance, implies a selling price of 92.886 . The insurance is thus worth an increase of 1.588 percent in selling prices. Analogously, a 28 basis point reduction in yield is worth something over 3.2 percent in increased prices.

Clearly the effect of bond insurance in the aftermarket for municipal bonds is quite important. Considerably more work needs to be done to understand the institutional context of this market and its relationship to the primary market for taxexempt debt. For example, the random sample of aftermarket transactions analyzed in this paper includes a large fraction (19 percent) of trades in bonds "naturally" rated aa, but for which insurance has been purchased. Conventional wisdom, based upon the market for new issues, says that it is not profitable to insure aa bonds. We suspect that aftermarket trades in the issues of smaller jurisdictions require higher yields than initial offerings with the same credit rating, reflecting differences in the level and timeliness of information about creditworthiness. We expect that analyses of the aftermarket can provide new insights about the role of information and signals in the market for tax-exempt debt.

\section{ENDNOTES}

**We are grateful to Kenny Information Systems, Inc. ("Kennybase") for making bond trade data available to us, and especially to Robert S. Bulka, Product Development Coordinator of Kenny S\&P Information Services, for his extraordinary help in data acquisition and data transfer. This paper could not have been completed without the capable assistance of Eric Hoffmann. We are also grateful for the comments of Roger Craine and those of an anonymous referee. Financial support for this research was provided by the Center for Real Estate and Urban Economics, University of California, Berkeley.

${ }^{1}$ Many of these are outlined in Petersen, et al [1988].

${ }^{2} \mathrm{~A}$ more detailed quantitative description of the industry and its recent history can be found in Quigley and Rubinfeld [1991].

${ }^{3}$ The WPPSS default involved some $\$ 2.25$ billion in revenue bonds and more than 78,000 investors. About $\$ 23.6$ million of this issue had been privately-insured. Prompt settlement of the insurance claims was widely reported in the financial and popular press.

4The use of guaranteed investment contracts (GIC's) in municipal bond finance is currently a subject of litigation in several states. The Tax Reform Act of 1986 placed severe limitations upon the arbitrage financing of tax-exempt municipal bonds (i.e., the ability of tax-exempt issuers to invest bond proceeds in interest-bearing securities, such as high-yield bonds, for "temporary" periods of up to three years). In response, some issuers turned to taxable municipal bonds, free of the arbitrage financing prohibition. By depositing the proceeds of taxable bonds, issuers could purchase GIC's from insurance companies that could, in turn, invest the proceeds in high yield "junk" bonds. At issue are the representations that resulted in the AAA ratings of the issues so "guaranteed." Pending litigation includes: Associated Kellogg Bank et al v. Louisiana Agricultural Finance Authority et al (United States District Court, Eastern District of Louisiana); Farm Bureau Town and Country Insurance Co. et al v. El Paso Housing Finance Corporation et al (United States District Court, Western District of Texas).

${ }^{5}$ Bonds sold from the specified portfolio are not insured, and changes in the creditworthiness of issues after purchase may thus lead to capital losses to investors upon sale. For this reason, bonds whose riskiness has increased are less likely to be sold out of portfolios insured in this manner. Bonds issued by agencies in default are still held in some unit trusts and bond funds, and their yield to investors is the same as it was when they were acquired.

${ }^{6}$ This is, of course, exactly the action taken when a jurisdiction purchases a credit analysis from one of the independent rating agencies.

${ }^{7}$ Reported sales are probably not a random sample of all municipal placements. They exclude small negotiated placements and some of those made by smaller jurisdictions.

${ }^{8} \mathrm{NIC}$ is defined as total interest payable minus any bid discount, divided by the par value of the issue times the average maturity. See Hendershott and Kidwell [1978] for a discussion of the shortcomings of this measure.

${ }^{9}$ The Moody's indices are based upon the yields on 20 different securities. The Composite Index is based 
on the yields on U.S. Treasury obligations neither due nor callable in less than 20 years.

${ }^{10}$ Interest rates are measured weekly throughout this analysis.

${ }^{11}$ The results are essentially the same when Standard and Poor's credit ratings are used instead of Moody's. In both cases, an unexpected negative coefficient is estimated for one class of lower grade securities (i.e., Moody's Baa). We subsequently discovered that this coefficient is based entirely on 26 trades in five different uninsured securities, all issued by a single agency, the government of the District of Columbia (DC). These DC issues are exempt from state and local, as well as federal taxes. Presumably, this difference in tax treatment underlies the lower yields for the 26 trades in Baa bonds in this sample.

${ }^{12}$ This is not quite true. Intertemporal changes in the creditworthiness of a security are not accounted for directly. If it were not for the time varying aspects of the transactions, the effects of insurance on pricing would be directly observable as yield differentials.

\section{REFERENCES}

Bland, Robert L., "The Interest Cost Savings from Municipal Bond Insurance: The Implications for Privatization," Journal of Policy Analysis and Management, 1987, pp. 207-219.

Bland, Robert L. and Chilik Yu, "Municipal Bond Insurance: An Assessment of Its Effectiveness at Lowering Interest Costs," Government Finance Re- view, June 1987, pp. 23-26.

Campbell, Tim and William Kracaw, "Information Production, Market Signalling and the Theory of Financial Intermediation" Journal of Finance, Vol. 35, Sept. 1980 , pp. $863-882$.

Kidwell, David, Eric Sorensen, and John Wachowicz, "Estimating the Signaling Benefits of Debt Insurance: The Case of Municipal Bonds," Journal of Financial and Quantitative Analysis, September 1987, pp. 299-313.

Petersen, John E., et. al., Credit Pooling to Finance Infrastructure: An Examination of State Bond Banks, State Revolving Funds, and Substate Credit Pools, Government Finance Research Center of the Government Finance Office Association, 1988.

Quigley, John M. and Daniel L. Rubinfeld, "Private Guarantees for Municipal Bonds: Institutions and Economic Outcomes," Center for Real Estate and Urban Economics Working Paper 91-191, University of California, Berkeley, April 1991.

Rindlaub, John W., "Municipal Bond Insurance," in Financial Guarantee Insurance, Insurance Information Institute, New York, 1986.

Ross, S. A., "The Determination of Financial Structure: The Incentive-Signalling Approach," Bell Journal of Economics and Management Science, Spring 1977, pp. 23-40.

Thakor, A. V., "An Exploration of Competitive Signaling Equilibria with 'third Party' Information Production: The Case of Debt Insurance," Journal of Finance, June 1982, pp. 717-739. 
Copyright of National Tax Journal is the property of National Tax Association. The copyright in an individual article may be maintained by the author in certain cases. Content may not be copied or emailed to multiple sites or posted to a listserv without the copyright holder's express written permission. However, users may print, download, or email articles for individual use. 